\title{
Processes and Mechanisms of Phosphorus Mobility Among Sediment, Water and Cyanobacteria Under Hydrodynamic Conditions
}

Lingxiao Ren ( $\nabla$ rlxjht@gmail.com )

Nanjing Institute of Technology

Keqiang Ding

Nanjing Institute of Technology

Zhixin Hu

Nanjing Institute of Technology

Huiya Wang

Nanjing Institute of Technology

Ning Qi

Chongqing Technology and Business University

Wei Xu

Nanjing Institute of Technology

\section{Research Article}

Keywords: Hydrodynamic intensity, Phosphorus mobility, Sediment, Microcystis aeruginosa, redox conditions

Posted Date: March 15th, 2021

DOI: https://doi.org/10.21203/rs.3.rs-160485/v1

License: (9) This work is licensed under a Creative Commons Attribution 4.0 International License. Read Full License

Version of Record: A version of this preprint was published at Environmental Science and Pollution Research on September 9th, 2021. See the published version at https://doi.org/10.1007/s11356-02116255-6. 


\section{Abstract}

Phosphorus $(P)$ has an important role in eutrophication and it is essential to explore the processes and mechanisms of $\mathrm{P}$ mobility in natural waters. In this study, laboratory experiments were conducted to simulate the SW system (sediment and water) and SAW system (sediment, algae and water) under four hydrodynamic intensity conditions (static control, $50 \mathrm{rpm}, 125 \mathrm{rpm}$ and $200 \mathrm{rpm}$ treatments), to investigate P mobility. Results in SW system showed that, sediment was an important source of P for overlying water, and the released total $P(T P)$ increased with stronger hydrodynamic intensity, when $P$ associated with metal pools (redox-sensitive $\mathrm{P}[\mathrm{BD}-\mathrm{P}]$ and meta-oxides bound $\mathrm{P}[\mathrm{NaOH}-\mathrm{P}]$ ) were the most unstable and easier to migrate into the overlying water. Stronger hydrodynamic disturbances could enhance the processes including sediment resuspension, dissolution of particles, and release of $P$, when $P$ mobility had a close relationship with redox conditions near sediment-water interface (SWI). Therefore, the release of TP, BD-P and NaOH-P from sediment increased and decreased in the control and 50-200 rpm treatments over time. In SAW system, the release of TP significantly increased from sediment comparing to SW system, and the growth of Microcystis aeruginosa could selectively enhance the release of $\mathrm{BD}-\mathrm{P}, \mathrm{NaOH}-\mathrm{P}$, and organic $\mathrm{P}(\mathrm{OP})$. Meanwhile, the released $\mathrm{P}$ from sediment was quickly accumulated by algal cells. The maximum accumulation ability of $\mathrm{P}$ by cells, the highest photosynthetic efficiency and the best growth of $M$. aeruginosa were observed in $125 \mathrm{rpm}$ treatment. But with excessively strong hydrodynamic intensity (200 rpm treatment), the accumulation ability of $\mathrm{P}$ and alkaline phosphatase activity (APA) of $M$. aeruginosa was suppressed, which might hinder algal utilization of $P$ and inhibit algal growth. Overall, our findings demonstrated the patterns of $\mathrm{P}$ mobility in natural ecosystems and could contribute to the understanding of $P$ cycling.

\section{Introduction}

Eutrophication has negatively affected aquatic ecosystems worldwide over the last several decades (Smith 2003; Glibert et al. 2011; Paerl et al. 2011), and it was reported to be mainly driven by increasing anthropogenic nutrient inputs from domestic sewage, agricultural and industrial wastewater (Smith et al. 1999; Xu et al. 2010; Wang et al. 2019). For a long time, harmful algal blooms (HABs) are a typical troubling indicator of eutrophication, which could cause hypoxia, disrupt food webs, produce various toxic secondary metabolites, etc. (Paerl and Scott 2010; Reynold 2006). As an important component of HABs, cyanobacteria are of particular concern from the environmental degradation and human health perspectives (Whitton and Potts 2002; Rigosi et al. 2014). Therefore, understanding nutrient cycling and adopting management methods have been widely recognized as essential for reducing eutrophication and the associated HABs in aquatic ecosystems (Carey et al. 2012).

Phosphorus $(P)$ is an essential element for many organisms and its availability has a critical role in the control of primary production in water (Smith et al. 1999; Deng et al. 2014). Although recent studies showed that dual nutrient (nitrogen \& P) reductions are essential to control HABs (Wang et al. 2014; Paerl et al. 2016), it was indicated that cyanobacteria blooms in eutrophic lakes were often coincident with an increase of total P (TP) concentration in the overlying water (Havens 2003; Zhu et al. 2013). As a result, 
external P input restrictions are widely implemented in the eutrophic systems, which have slowed eutrophication and reduced HABs potentials in many regions (Schindler 1977; Carpenter 2008).

Meanwhile, internal $\mathrm{P}$ could also contribute to high $\mathrm{P}$ loadings in the overlying water and might affect the magnitude, frequency and duration of HABs (Ding et al. 2018; Paytan et al. 2017). Since sediment represented an important internal source and could release a lot of contaminants in aquatic ecosystems (Luthy et al. 2004; Mozeto et al. 2014), the P cycling processes among sediment, water and phytoplankton have been a hot research topic for many years.

Especially, the behaviors and mechanisms of $\mathrm{P}$ mobility between sediment and overlying water were widely studied, which have a close relationship with the physico-chemical conditions (Cyr et al. 2009; Katsev and Dittrich 2013). For example, iron (Fe) played a key role in controlling the release of $P$ from sediment and the accumulated $\mathrm{P}$ could be released more rapidly by reductive dissolution of Fe oxides in anoxic waters (Chen et al. 2019). The mobility of $P$ from sediment was significantly affected by water disturbances and sediment resuspension, which were common situations in eutrophic lakes in the middle and lower reaches of Yangtze River are shallow lakes (Zhang et al. 2006). However, studies examining the effects of different intensities of hydrodynamic conditions on $\mathrm{P}$ mobility are not sufficient. Moreover, researches have less considered the roles of algae, particularly for cyanobacteria species, which had a feedback on P mobility between sediment and overlying water (Cao et al. 2016; Xie et al. 2003). For example, some $P$ fractions in the sediment were available for cyanobacterial growth, which could in turn cause the variations of physico-chemical properties of overlying water and sediment (Giles et al. 2016). Additionally, hydrodynamic disturbance could directly affect the growth of phytoplankton (Huang et al. 2015), and it is crucial to study the multi-medium mobility of $P$ under different hydrodynamic conditions.

In this study, sediments and overlying water in typical bloom areas were exposed to different hydrodynamic intensity conditions using four rotation speeds in columnar beakers. A bloom-forming cyanobacterium was also selected and introduced into the systems. The goals of our study were to: (1) investigate the processes and mechanisms of $\mathrm{P}$ mobility among multi-mediums, (2) explore the responses of cyanobacteria, (3) explain the effects of cyanobacteria on P mobility.

\section{Materials And Methods}

\subsection{Sampling area and experimental design}

Our research selected Meiliang Bay as the sampling area, which is located in the northern areas of Lake Taihu (Fig. S1, $31^{\circ} 25^{\prime} 00^{\prime \prime} \mathrm{N}, 120^{\circ} 12^{\prime} 57^{\prime \prime} \mathrm{E}$ ) and is one of the areas where HABs often broke out seriously (Xu et al. 2010). Especially, this region has been suffered from cyanobacteria for a long time and water quality was deteriorated ever since the early 1980s, switched to the eutrophic state in 1990s, and became hyper-eutrophic in recent years (Zhang et al. 2020). Meanwhile, the resuspension of sediment often occurred in this area caused by natural wind forces. 
After sampling, the overlying water and sediment were immediately pretreated and used in the incubation experiment (Fig. S2). Detailed procedures of sampling and experimental setup can be seen in SI. Based on rotation speed, four treatments were set (0 rpm control treatment, $50 \mathrm{rpm}, 125 \mathrm{rpm}$ and $200 \mathrm{rpm}$ treatments). Meanwhile, two incubation systems were defined, including SW system (containing sediment and water) and SAW system (containing sediment, algae and water).

\subsection{Analyses of water samples}

Based on our preliminary experiments, the vertical distributions of turbidity under four hydrodynamic conditions reached a relative stable stage after the withdrawal of stirring for $5 \mathrm{~h}$, when turbidity showed no significant differences above the depth of $15 \mathrm{~cm}$ in the same treatment (Fig. S3; p > 0.05). Accordingly, after the twice-daily stirring with different intensities (8:00-8:30 and 12:00-12:30), the overlying water were collected from the sidewall of cylinders at 17:30 at a depth of $15 \mathrm{~cm}$ with syringe samplers (W-pore, Fig. S2), for determining TP, total dissolved P (TDP) and particle P (PP). Based on continuous flow systems (SEAL AutoAnalyzer 3, Germany), P could be determined using colorimetric detection of the molybdenum blue method (Murphy and Riley 1962). Meanwhile, size of suspended particles was determined using a laser analyzer (Malvern 2000, UK), which was important to estimate the degree of sediment resuspension (Qian et al. 2011). After each sampling, the ultrapure water was supplemented to maintain the stability of incubation system.

The apparent diffusion of $\mathrm{P}$ between sediment and overlying water was a two-way process (Yao et al. 2016a), and we focused on the area near sediment-water interface (SWI) to specify P mobility. Water near SWI was regularly sampled at $5 \mathrm{~mm}$ intervals $(20 \mathrm{~mm}$ above and $40 \mathrm{~mm}$ below the SWI, respectively) for determining TDP (Fig. S2) with special sampling apparatus (Rhizons MOM), which has been widely adopted to collect water for analyzing macro and micro elements in disturbed sediments (Ding et al. 2019). Since SWI was the plane where overlying water and sediment met, water samples below SWI could be considered as pore water in sediment. After collecting water samples near SWI, pH, dissolved oxygen (DO) content, and redox potential were quickly and directly determined using a YSI-multi parameters probe.

\subsection{Analyses of sediment samples}

At the beginning (Day 1) and during experiment (Day 4 and Day 10), sediment samples were collected with a pipetting device, which could reduce the disturbances of water. In order to make sure of the homogeneity, three discrete samples of sediment at different positions were collected in each cylinder (Spore, Fig. S2) and samples were mixed for further analysis.

Based on the Standard Measurements and Testing (SMT) sequential extraction method (Rydin et al. 2000; Psenner et al. 1988), a modified method was used to measure P fractions in sediment (Fig. S4). On one hand, the following five forms of $\mathrm{P}$ were present: $\mathrm{NH}_{4} \mathrm{Cl}-\mathrm{P}$ (loosely-bound $\mathrm{P}$ ), $\mathrm{BD}-\mathrm{P}$ (redox-sensitive $\mathrm{P}$ ), $\mathrm{NaOH}-\mathrm{P}$ (metal-oxides bound $\mathrm{P}$ ), Ca-P (apatite bound $\mathrm{P}$ ), and Res-P ( $\mathrm{P}$ with low reactivity). Meanwhile, inorganic $P(I P)$ and organic $P(O P)$ were also determined. Contents of $P$ fractions in the initial sediment were shown in Table S1. 
Total contents of metals as Fe, aluminum (Al), calcium (Ca) and manganese (Mn) were measured by ICPAES method after digestion (Table S1). The ammonium oxalate-oxalic acid extract was used to yield active Fe and active Al (Zhou et al. 2005). Loss of ignition (LOI) was based on weight losses after combustion at $550^{\circ} \mathrm{C}$. Meanwhile, the total organic carbon (TOC) was determined using a total organic carbon analyzer (Malvern liquid TOC, UK) after treating with chromic acid/ $\mathrm{H}_{2} \mathrm{SO}_{4}$.

\subsection{Analyses of cyanobacteria}

\subsubsection{Algae cultures}

Microcystis aeruginosa 905 was obtained from Freshwater Algae Culture Collection of the Institute of Hydrobiology, Chinese Academy of Sciences (FACHB). The details of inoculation and expanding cultures can be seen in Ren et al. (2020). Cell density was monitored daily until it exceeded $2 \times 10^{7}$ cells $\mathrm{mL}^{-1}$. Then, $M$. aeruginosa was harvested by centrifugation (5000 $\mathrm{g}$ for $10 \mathrm{~min}, 4^{\circ} \mathrm{C}$ ), washed with ultrapure water, and transferred into cylinders containing sediment and lake water, which represented SAW system. The initial cell density was $1 \times 10^{6}$ cells $\mathrm{mL}^{-1}$, which was approximately to the value at the beginning of typical algal blooms in Lake Taihu (Chen et al. 2003).

\subsubsection{Parameters of $M$. aeruginosa}

Considering the interferences caused by suspended particles in the overlying water, the phytoplankton analyzer (Phyto-PAM, Hein Walz, Germany) was used to determine chlorophyll a (chl-a) and the effective quantum yield $\left(F_{v} / F_{m}\right)$ of $M$. aeruginosa (Jakob et al. 2005), which could indicate the function of algal photosystem II (PS II) system.

After the twice-daily stirring and standing still for $5 \mathrm{~h}, 5 \mathrm{~mL}$ of overlying water was collected (W-pore, Fig. S2) and filtered through $5-\mu \mathrm{m}$ polyester filters (Whatman). Since the total amount of $\mathrm{P}$ associated with filters can be calculated after rinsing and direct digestion in the colorimetric tubes $\left(120^{\circ} \mathrm{C}, 150 \mathrm{kPa}\right)$, algal cells retained on the filters were dissolved by stepwise extraction using trichloroacetic acid, ethanol, ethanol/ether (3:1 by volume), and sodium hydroxide $(\mathrm{NaOH})$, to estimate cellular P quota of $M$. aeruginosa (Jeffries et al. 1979; Powell et al. 2008). The cell density of $M$. aeruginosa was directly monitored with an optical microscope (Zeiss Axioskop 40, Germany).

After sampling overlying water, $p$-nitrophenylphosphate ( $p N P P)$ was also directly added for determining alkaline phosphatase activity (APA), which has been reported to be important for algal utilization of dissolved organic $P$ (DOP) and its prosperity in the natural waters (Ren et al. 2015). Moreover, fluorescence-labeled enzyme activity (FLEA) technique was also used to illustrate APA of M. aeruginosa. The details of measurement can be seen in SI.

To explorer the microstructure of cells, scanning electron microscopy (SEM) was conducted for $M$. aeruginosa on Day 8. Cells were harvested by centrifugation (5000 $\mathrm{g}$ for $10 \mathrm{~min}, 4^{\circ} \mathrm{C}$ ) and the methods were adopted from Ren et al. (2020). 


\subsection{Statistical analysis}

All vessels were sterilized via autoclaving at $121^{\circ} \mathrm{C}$ and $150 \mathrm{kPa}$ for $30 \mathrm{~min}$ before use, and solutions were prepared using ultrapure water and analytical-grade chemicals. In our study, experiments were conducted in triplicate and means \pm standard deviations were calculated. Parametric three-way repeatedmeasures analysis of variance (RM-ANOVA) was adopted to determine the effects of hydrodynamic intensity, sampling time, and cyanobacteria on P mobility (Table S2). Data were tested for the normality and variance assumptions of ANOVA, and no data transformation was needed. If the interaction factor was significant at $p<0.05$, a one-way ANOVA followed by Tukey's test was used to determine where differences lie. All statistical analyses were performed using SPSS 22.0 (SPSS Inc., Chicago, IL, USA).

\section{Results And Discussion}

\subsection{P mobility in the SW system \\ 3.1.1 $\mathrm{P}$ fractions in the overlying water}

In the control treatment, TP increased slowly and reached its maximum on Day 14 (Fig. 1, $0.38 \mathrm{mg} \mathrm{L}^{-1}$ ). By comparison, TP was higher $(\mathrm{p}<0.05)$ on the same day in the other treatments, and the maximum values varied between $0.54-0.83 \mathrm{mg} \mathrm{L}^{-1}$ on Day 14 . The increase of $\mathrm{P}$ in the overlying water could only come from sediment in the SW system and the results showed that, TP release from sediment under hydrodynamic conditions could be divided into sharp release, relaxedly release and equilibrium release periods, when the release rates and equilibrium concentrations of TP were higher with stronger hydrodynamic intensity $(p<0.05)$. By comparison, TDP increased persistently during experiment and stronger hydrodynamic intensity also accelerated this process $(p<0.05)$. However, except for the control treatment, PP increased rapidly before Day 6 and it decreased during Day 6-14.

\subsubsection{TDP in the water near SWI}

In our study, TDP in the water near SWI (depth above SWI represented overlying water, depth below SWI represented pore water) was determined in Fig. 2.

In the control treatment, TDP gradually increased with the sampling sites moving down, and the variation tendency was similar during the whole experiment. But in the other treatments, TDP was maximum at SWI (depth $=0 \mathrm{~mm}$ ) on Day 2, which indicated the accumulation of $\mathrm{P}$ from sediment after hydrodynamic disturbances. On Day 6, TDP at SWI both increased a lot in $50 \mathrm{rpm}, 125 \mathrm{rpm}$ and $200 \mathrm{rpm}$ treatments, and it was higher under stronger hydrodynamic intensity conditions $(p<0.05)$. But on Day 10, TDP in the water near SWI kept increasing in the control treatment and decreased in the other treatments.

\subsubsection{Changes of $P$ fractions in the sediment}


Compared to the initial content, TP in the sediment decreased by $29.8-96.5 \mathrm{mg} \mathrm{kg}^{-1}$ on Day 4 (Fig. 3a), which directly indicated a considerable release of $P$ from sediment. Meanwhile, the largest reduction was observed for BD-P and NaOH-P content on Day 4 (15.02-43.27 $\mathrm{mg} \mathrm{kg}^{-1}$ and 13.14-45.27 $\mathrm{mg} \mathrm{kg}^{-1}$ ), which suggested the greatest release of BD-P and $\mathrm{NaOH}-\mathrm{P}$. The release of TP, BD-P and NaOH-P raised correspondingly with stronger hydrodynamic intensity. On the contrary, $\mathrm{NH}_{4} \mathrm{Cl}-\mathrm{P}$ increased slightly and $\mathrm{HCl}-\mathrm{P}$ increased greatly on Day 4 in 50-200 rpm treatments. In addition, although sediment released more IP in different treatments on Day $4\left(17.71-48.04 \mathrm{mg} \mathrm{kg}^{-1}\right)$, the released $\mathrm{P}$ contained a considerable part of OP.

With experiment progressed, the reduction of BD-P and $\mathrm{NaOH}-\mathrm{P}$ increased in the control treatment on Day 10. However, the reduction of BD-P and NaOH-P decreased in 50-200 rpm treatments, which reached 14.17-30.87 $\mathrm{mg} \mathrm{kg}^{-1}$ and $12.47-28.37 \mathrm{mg} \mathrm{kg}^{-1}$ comparing to initial content, respectively. Meanwhile, OP kept relative stable on Day 10 in different treatments, but the reduction of IP increased and decreased significantly $(p<0.05)$ in the control and 50-200 rpm treatments, respectively, indicating the greater migration of IP.

\subsubsection{Variations of physio-chemical parameters}

Redox conditions near SWI were important for P mobility and they were measured during the experiment. On Day 2, DO content decreased with sampling sites moving down and DO content at the same depth increased with stronger hydrodynamic intensity (Fig. 4a). On Day 8, DO near SWI was almost depleted in the control treatment and high DO content near SWI was observed in the other treatments, when the penetration of oxygen into sediment was restricted to the top $3-4 \mathrm{~cm}$. The variation patterns of redox potential were consistent with DO content, which had a downward trend and increased with stronger hydrodynamic intensity (Fig. 4b). With experiment progressed, SWI was under the reduction condition on Day 8 in the control treatment (redox potential $<0$ ), but SWI in the other treatments were both in oxidation state.

Whether the size composition or average median particle size $\left(D_{50}\right)$, results both showed that suspended particles contained an increased fraction of larger particles over time in 50-200 rpm treatments (Fig. 4c). Moreover, the fraction of 63-2000 $\mu \mathrm{m}$ particles increased significantly $(p<0.05)$ under stronger hydrodynamic intensity conditions, which indicated the most intense sediment resuspension in $200 \mathrm{rpm}$ treatment. This was consistent with Qian et al. (2011) that, larger particles were low viscid and they were more easily migrated from sediment into the overlying water with stronger disturbances.

\subsubsection{Processes of P mobility in the SW system}

Zhu et al. (2013) thought that internal P loading of Lake Taihu should be addressed from a nutrient management perspective. Our results also confirmed that, sediment in Meiliang Bay had a high potential to release $\mathrm{P}$ and could contribute to eutrophication development. It could be related to high contents of $\mathrm{Fe}$ and Al in the sediment (Table S1), which were considered to mainly determine the adsorption capacity of sediment (Brinkman 1993; Cyr et al. 2009). Moreover, the ratios of active Fe and Al in Meiliang Bay were 
also high ( $>60 \%)$, and sediment could have a great ability to release $\mathrm{P}$ when hydrodynamic conditions permitted (Zhou et al. 2005). Based on TDP concentrations in the water above and below SWI, P mobility between sediment and overlying water was mainly determined by TDP concentration gradient in the control treatment, which occurred at a slower rate. Meanwhile, P mobility in 50-200 rpm treatments could be directly influenced by the hydrodynamic forces, which would further affect sediment resuspension, dissolution of particles, and release of $\mathrm{P}$ fractions. As a consequence, stronger hydrodynamic intensities increased the shear stress of water and enhanced the above processes (Tammeorg et al. 2015; Zheng et al. 2013), which resulted to larger accumulation of TDP at SWI and the greater increase of $P$ fractions in the overlying water. This deduction was confirmed by the distribution of suspended particles under stronger hydrodynamic intensity conditions, when more sand particles were transferred from the sediment.

Changes of $\mathrm{P}$ fractions in the sediment indicated that, $\mathrm{P}$ associated with metal pools were the most unstable and easier to migrate by hydrodynamic drivers. Hu et al. (2007) also reported that, water in Lake Dianchi tended to be more eutrophic with more BD-P and NaOH-P in the sediment. Meanwhile, although scholars thought that only inorganic phosphate could bind with metal complexes (Ruban et al. 2001; Zhu et al. 2013), it was reported that metal oxides could also bound with OP in the sediment (Bai et al. 2009). As a result, this part of OP was labile and easily to be released from sediment under hydrodynamic conditions in our study, which could have an important role in $\mathrm{P}$ cycling in aquatic systems (Puttonen et al. 2014). By comparison, $\mathrm{NH}_{4} \mathrm{Cl}-\mathrm{P}$ was bounded by the weaker sorption and acted more as an intermedium between sediment and overlying water (Mort et al. 2010), resulting to an increase of $\mathrm{NH}_{4} \mathrm{Cl}-\mathrm{P}$. A possible reason for the increase $\mathrm{HCl}-\mathrm{P}$ was that sediment released more $\mathrm{Ca}$ ions under hydrodynamic conditions, which adsorbed phosphate and settled back into the sediment (Lukkari et al. 2009).

As has been reported (Smith et al. 2011; Sinkko et al. 2013), dissolution and mobility of metal-bound P increased under reduction conditions. In SW system, this process was dominant in the control treatment, when DO near SWI was depleted and the redox conditions became progressively reduced. Consequently, sediment could release more BD-P, NaOH-P on Day 10. However, with DO content and redox potential near SWI increasing in 50-200 rpm treatments, high-valence metal ions (mainly referred to Fe and $\mathrm{Mn}$ ) and their oxides in sediment enhanced the adsorption of P pools (Katsev and Dittrich 2013), leading to increased BD-P and NaOH-P contents on Day 10. In addition, P mobility in SW system was actually the imbalance between $P$ sedimentation in the overlying water and $P$ release from the sediment (Elser and Bennett 2011). In our study, sizes of suspended particles increased gradually and larger particles were more liable to drop down (Yao et al. 2016b). This could enhance P retention and lead to the decreased PP in the overlying water after Day 6.

\subsection{P mobility in the SAW system \\ 3.2.1 Growth of M. aeruginosa}


M. aeruginosa grew slowly in the control treatment and the maximum chl-a was observed on Day 14 (Fig. 5a). With stronger hydrodynamic intensity, the highest growth rates and largest biomass were observed in $125 \mathrm{rpm}$ treatment, when the exponential growth was also longer (Day 4-14). By comparison, the growth of $M$. aeruginosa was suppressed in $200 \mathrm{rpm}$ treatment, when chl-a increased slowly before Day 8 and it quickly decreased afterwards. SEM analysis also indicated the best growth of algae in $125 \mathrm{rpm}$ treatment (Fig. 5b). The spherical shape and surface morphology of cells on Day 8 did not obviously change in control, $50 \mathrm{rpm}$ and $125 \mathrm{rpm}$ treatments, when cell surfaces were glossy and intact. However, the surfaces of algal cells were rough and damaged in $200 \mathrm{rpm}$ treatment, indicating the negative effects on algae.

The variation manners of $F_{v} / F_{m}$ were synchronous with those of chl-a and highly related to hydrodynamic intensity (Fig. 5c). In the control, $50 \mathrm{rpm}$ and $125 \mathrm{rpm}$ treatments, $F_{v} / F_{m}$ both gradually increased before Day 7 and remained relatively constant afterwards, when $F_{v} / F_{m}$ was highest in $125 \mathrm{rpm}$ treatment during the whole experiment. By comparison, $F_{v} / F_{m}$ was lowest in $200 \mathrm{rpm}$ treatment and decreased after Day 7.

\subsubsection{Cellular P quota and APA}

In the control treatment, cellular P quota of M. aeruginosa increased slowly before Day 6 and exhibited a slight fluctuation afterwards. By comparison, it sharply increased (maximum on Day 4) and decreased afterwards in the other treatments (Fig. 6a). It was consistent with Powell et al. (2009) that, microalgae could quickly accumulate $P$ from surrounding waters by "luxury uptake", which did not require a prior $P$ starvation. Under hydrodynamic conditions, cellular P quota was highest in $125 \mathrm{rpm}$ treatment and it was lower in $200 \mathrm{rpm}$ treatment.

In the control, $50 \mathrm{rpm}$ and $125 \mathrm{rpm}$ treatments, APA kept increasing before Day 8 and it remained steady afterwards, when it was lower with the stronger hydrodynamic intensity (Fig. 6b). Since sediment released $O P$ to varying degrees in different treatments, the adsorbed $P$ by algal cells could induce the increase of APA (Ren et al. 2017). However, APA decreased from the beginning in $200 \mathrm{rpm}$ treatment and it was lowest during the experiment. Results of FLEA images also indicated the highest APA of algae in $125 \mathrm{rpm}$ treatment (Fig. 6c), when the ratio of fluorescence-labeled cells were large. In comparison, a relatively low number of cells was observed in the $200 \mathrm{rpm}$ treatment.

\subsection{3 $\mathrm{P}$ fractions in the overlying water}

The variation patterns of $P$ fractions in the overlying water were significantly different $(p<0.05)$ between SW and SAW systems (Table S2), indicating that $M$. aeruginosa might greatly change $P$ mobility between multi-mediums. In SAW system, TDP also gradually increased but the rising speed became lower $(\mathrm{p}<$ 0.05 , Fig. $7 a$ ). This pattern was particularly evident in the control treatment, when TDP remained constant during the whole experiment.

Although PP in the overlying water did change obviously in SW system in the control treatment, it gradually increased in SAW system (Fig. 7b). Meanwhile, the continuous and greater increase of PP was 
observed in $50 \mathrm{rpm}$ and $125 \mathrm{rpm}$ treatments. But in the $200 \mathrm{rpm}$ treatment, PP reached the maximum on Day 4 and decreased afterwards.

\subsubsection{Changes of $P$ fractions in the sediment}

Compared to the control, $50 \mathrm{rpm}$ and $125 \mathrm{rpm}$ treatments in SW system (Fig. 3a), release of TP from the sediment increased significantly $(\mathrm{p}<0.05)$ on Day 4 in the SAW system (Fig. $3 \mathrm{~b})$, indicating that $M$. aeruginosa caused a greater $\mathrm{P}$ mobility from sediment. Moreover, the reduction of $\mathrm{NH}_{4} \mathrm{Cl}-\mathrm{P}, \mathrm{BD}-\mathrm{P}, \mathrm{NaOH}-\mathrm{P}$ on Day 4 was also higher $(p<0.05)$ comparing to those in SW system. Meanwhile, except for $200 \mathrm{rpm}$ treatment when growth of $M$. aeruginosa was poor, sediment significantly increased the release of OP in the other treatments on Day $4\left(\mathrm{p}<0.05,6.89-12.58 \mathrm{mg} \mathrm{kg}^{-1}\right)$ comparing to that in SW system.

As mentioned above, with DO content and redox potential near SWI increasing (Fig. S5), P adsorption by metal oxides could be enhanced. Therefore, reduction of BD-P and NaOH-P in the sediment decreased obviously on Day 10 (Fig. 3b). Meanwhile, reduction of OP content in the sediment also decreased a lot on Day 10.

\subsection{Effects of hydrodynamic conditions on cyanobacteria}

Our results have shown that, stronger hydrodynamic forces directly promoted P release from the sediment. It was consistent with previous studies who reported that, a certain degree of hydrodynamic turbulence provided algae with favorable ecological resources during period of HABs (Brunberg and Blomqvist 2010). However, $M$. aeruginosa showed the maximum accumulation ability of $P$, the highest photosynthetic efficiency and the best growth in $125 \mathrm{rpm}$ treatment. It could be explained by the fact that, hydrodynamic forces could scour and decrease the thickness of extracellular polymeric substances (EPS) of algal cells (Xu et al. 2013), which subsequently affected the accumulation ability of P by $M$. aeruginosa. Moreover, the uptake and $\mathrm{P}$ utilization by $M$. aeruginosa required the transport process of $\mathrm{P}$ through cell membrane and a large part of accumulated P was surface-adsorbed (Yao et al. 2011), when the excessively strong hydrodynamic forces decreased the binding between $P$ and cells. Furthermore, growth of phytoplankton was highly dependent on its photosynthetic efficiency and other metabolism process, which could be suppressed in excessively turbulent waters (Ruttenberg and Dyhrman 2012).

Mineralization of OP is important for phytoplankton, and APA of $M$. aeruginosa decreased under stronger hydrodynamic intensity conditions in our study. It was consistent with Hiatt et al. (2018), who pointed that periphytic-APA was inhibited with faster velocity and expression of enzyme activity was higher in static waters. Ma et al. (2019) used APA as a supplemental index to predict HABs in Lake Taihu and obtained similar results. However, the negative effects of stronger hydrodynamic conditions on APA was also probably due to the greater release of IP from sediment, as higher APA reflected an alternative pathway for acquiring IP by algae.

\subsection{Effects of cyanobacteria on P mobility}

Compared to SW system, our study showed a greater release of TP from sediment in SAW system, whereas a significant part of released $\mathrm{P}$ was quickly acquired by $M$. aeruginosa. The accumulation ability 
of inorganic phosphate and DOP by typical cyanophyta and chlorophyta species has been investigated in our previous study (Ren et al. 2017), which could benefit their competitive strategy and growth. Therefore, TDP in the overlying water of SAW system was drawn down by the nutritional needs of $M$. aeruginosa, which explained why some natural waters with low P content still exhibited outbreaks of cyanobacterial blooms (Cao et al. 2016; Ma et al. 2019). Our results also indicated the synergistic effect between cyanobacterial growth and $\mathrm{P}$ release from sediment. Therefore, worse water quality and outbreaks of HABs in many shallow lakes often occurred after a certain intensity of hydrodynamic disturbances (Zhou et al. 2015). Meanwhile, the $P$ release from sediment by $M$. aeruginosa was selectively enhanced, which herein referred to $\mathrm{NaOH}-\mathrm{P}, \mathrm{BD}-\mathrm{P}$, and OP. The influence mechanisms of $M$. aeruginosa on $\mathrm{P}$ mobility could be explained by the following facts.

Firstly, $M$. aeruginosa could directly promote its physiological requirement of $\mathrm{P}$ and promote the mineralization of OP. It agreed with Chao et al. (2011) who carried out an in situ experiment in Lake Taihu and reported that, the adsorption and biological transformation of $\mathrm{P}$ by algae were the main causes of increased $P$ release from sediment under the wind-induced disturbances. As a result, with algal APA increasing during our incubation, the release of OP from sediment significantly increased in SAW system on Day 4. The decreased release of OP in $200 \mathrm{rpm}$ treatment might be explained by the worst growth and lowest APA of $M$. aeruginosa. Secondly, as mentioned above, $\mathrm{P}$ mobility was vulnerable to the alterations of redox conditions (Katsev and Dittrich 2013). In SAW system, the growth and photosynthesis of $M$. aeruginosa accelerated the consumption of DO near SWI, when redox potential was also more reduced (Fig. S5). As a result, specific metal ions and their oxides in the sediment were more reductively dissolved and the adsorbed $P$ was released faster (Pearce et al. 2013; Giles et al. 2016), which resulted to the enhanced release of BD-P and $\mathrm{NaOH}-\mathrm{P}$ from sediment. Xie et al. (2003) also reported that microbial respiration consumed oxygen and promoted the dissolution of metal-bound $\mathrm{P}$ in sediment. And thirdly, $\mathrm{pH}$ could control the concentrations of available $\mathrm{Fe}, \mathrm{Al}$, and $\mathrm{Ca}$ ions, and thus change $\mathrm{P}$ mobility (Jin et al. 2006). In SAW system, pH in the overlying water increased following M. aeruginosa growth (Fig. S5), which could trigger the release of $\mathrm{P}$ from sediment by $\mathrm{OH}^{-}$ion exchange with $\mathrm{PO}_{4}{ }^{3-}$ on metal complexes.

In natural aquatic systems, the causes of sediment resuspension are complex and may not necessarily derive from hydrodynamic forces. Moreover, the compositions and characteristics of sediments also remained uncertain. These complexities deserve further study, along with the likely influence of coexisting but unexamined factors on P mobility.

\section{Conclusions}

(1) Sediment was a great source of P for overlying water under hydrodynamic conditions, and the release of $P$ from sediment increased with stronger hydrodynamic intensity. Meanwhile, $P$ associated with metal pools (BD-P and $\mathrm{NaOH}-\mathrm{P}$ ) were the most unstable and easier to migrate into the overlying water.

(2) Stronger hydrodynamic disturbances enhanced sediment resuspension, dissolution of particles, and the release of $\mathrm{P}$ fractions from sediment. $\mathrm{P}$ mobility between sediment and overlying water had a close 
relationship with redox conditions near SWI, when the release of TP, BD-P and $\mathrm{NaOH}-\mathrm{P}$ from sediment increased in the control treatment and decreased in 50-200 rpm treatments over time.

(3) In SAW system, presence of $M$. aeruginosa significantly promoted the release of TP from sediment, but the released $P$ could be quickly accumulated by $M$. aeruginosa, leading to a slower increase of TDP in the overlying water. Especially, the release of BD-P, NaOH-P, and OP from sediment was selectively enhanced in SAW system.

(4) $M$. aeruginosa exhibited the maximum accumulation ability of $P$, the highest photosynthetic efficiency and the best growth in $125 \mathrm{rpm}$ treatment. But in $200 \mathrm{rpm}$ treatment, algal accumulation ability of $\mathrm{P}$ and its APA was suppressed, which might hinder algal utilization of $P$ and inhibit its growth.

\section{Abbreviations}

SW system [sediment and overlying water]; SAW system [sediment, algae and overlying water]; TP [total phosphorus]; TDP [total dissolved phosphorus]; PP [particulate phosphorus]; BD-P [redox-sensitive phosphorus]; NaOH-P [meta-oxides bound phosphorus]; IP [inorganic phosphorus]; OP [organic phosphorus]; APA [alkaline phosphatase activity]

\section{Declarations}

Ethics approval and consent to participate: Not applicable

Consent for publication: Not applicable

Availability of data and materials: The datasets used and analyzed during the current study are available from the corresponding author on reasonable request.

Competing interests: The authors declare that they have no competing interests.

Funding: This work was financially supported by the Talent-Recruiting Program of Nanjing Institute of Technology (No. YKJ201845).

Authors' contributions: Lingxiao Ren: Data analyzing and writing original draft; Keqiang Ding: Methodology and establishments offering; Zhixin Hu and Huiya Wang: Reviewing and field sampling; Ning Qi and Wei Xu: Field sampling and language polishing. All authors read and approved the final manuscript

\section{Acknowledgments:}

We are grateful to all anonymous editors and reviewers for providing comments on this manuscript. We also appreciate the grants for Project supported by the Talent-Recruiting Program of Nanjing Institute of Technology (No. YKJ201845). 


\section{References}

1. Bai XL, Ding SM, Fan CX, Liu T, Shi D, Zhang L (2009) Organic phosphorus species in surface sediments of a large, shallow, eutrophic lake, Lake Taihu, China. Environ Pollut 157:2507-2513

2. Brinkman AG (1993) A double-layer model for ion adsorption onto metal oxides, applied to experimental data and to natural sediments of Lake Veluwe, The Netherlands. Hydrobiologia 253:31-45

3. Brunberg AK, Blomqvist P (2010) Recruitment of Microcystis (Cyanophyceae) from lake sediments. J Phycol 39:58-63

4. Cao X, Wang Y, He J, Luo X, Zheng Z (2016) Phosphorus mobility among sediments, water and cyanobacteria enhanced by cyanobacteria blooms in eutrophic Lake Dianchi. Environ Pollut 219:580-587

5. Carey CC, Ibelings BW, Hoffmann EP, Hamilton DP, Brookes JD (2012) Eco-physiological adaptations that favour freshwater cyanobacteria in a changing climate. Water Res 46:1394-1407

6. Carpenter SR (2008) Phosphorus control is critical to mitigating eutrophication. P Natl Acad Sci USA 105:11039-11040

7. Chao JY, Gao G, Tang XM, Dai JY, Zhuang W, Zhang YM (2011) Effects of wind-induced wave on organic aggregates physical and chemical characteristics in a shallow eutrophic lake (Lake Taihu) in China. Environ Sci 32:2861-2867 (in Chinese)

8. Chen MS, Ding SM, Wu YX, Fan XF, Jin ZF, Tsang DCW, Wang Y, Zhang CS (2019) Phosphorus mobilization in lake sediments: Experimental evidence of strong control by iron and negligible influences of manganese redox reactions. Environ Pollut 246:472-481

9. Chen YW, Qin BQ, Teubner K, Dokulil MT (2003) Long-term dynamics of phytoplankton assemblages: Microcystis-domination in Lake Taihu, a large shallow lake in China. 25: 445-453

10. Cyr H, Mccabe SK, Nürnberg GK (2009) Phosphorus sorption experiments and the potential for internal phosphorus loading in littoral areas of a stratified lake. Water Res 43:1654-1666

11. Deng J, Qin B, Paerl HW, Zhang Y, Wu P, Ma J, Chen Y (2014) Effects of nutrients, temperature and their interactions on spring phytoplankton community succession in Lake Taihu, China. Plos One 9:e113960

12. Ding J, Hua ZL, Chu KJ (2019) The effect of hydrodynamic forces of dryingwetting cycles on the release of soluble reactive phosphorus from sediment. Environ. Pollut. 252(Pt B): 992-1001

13. Ding SM, Chen MS, Gong MD, Fan XF, Qin BQ, Xu H, Gao SS, Jin ZF, Tsang DCW, Zhang CS (2018) Internal phosphorus loading from sediments causes seasonal nitrogen limitation for harmful algal blooms. Sci Total Environ 625:872-884

14. Elser J, Bennett E (2011) Phosphorus cycle: A broken biogeochemical cycle. Nature 478:29-31

15. Giles CD, Isles PDF, Manley T, Xu YY, Druschel GK, Schroth AW (2016) The mobility of phosphorus, iron, and manganese through the sediment-water continuum of a shallow eutrophic freshwater lake under stratified and mixed water-column conditions. Biogeochemistry 127:15-34 
16. Glibert PM, Burkholder JM (2011) Harmful algal blooms and eutrophication: "strategies" for nutrient uptake and growth outside the redfield comfort zone. Chin J Oceanol Limn 29:724-738

17. Havens KE (2003) Phosphorus-Algal Bloom Relationships in Large Lakes of South Florida: Implications for Establishing Nutrient Criteria. Lake Reserv Manage 19:222-228

18. Hiatt DL, Back JA, King RS (2018) Effects of stream velocity and phosphorus concentrations on alkaline phosphatase activity and carbon:phosphorus ratios in periphyton. Hydrobiologia 826:173182

19. Hu J, Shen QS, Liu YD, Liu JT (2007) Mobility of Different Phosphorus Pools in the Sediment of Lake Dianchi during Cyanobacterial Blooms. Environ Monit Assess 132:141-153

20. Huang J, Xu QJ, Xi BD, Wang XX, Li WP, Gao G, Huo SL, Xia XF, Jiang TT, Ji DF (2015) Impacts of hydrodynamic disturbance on sediment resuspension, phosphorus and phosphatase release, and cyanobacterial growth in Lake Tai. Environ Earth Sci 74:3945-3954

21. Jeffries DS, Dieken FP, Jones DE (1979) Performance of the autoclave digestion method for total phosphorus analysis. Water Res 13:275-279

22. Jin XC, Wang SR, Pang Y, Wu FC (2006) Phosphorus fractions and the effect of pH on the phosphorus release of the sediments from different trophic areas in Taihu Lake, China. Environ Pollut 139:288-295

23. Katsev S, Dittrich M (2013) Modeling of decadal scale phosphorus retention in lake sediment under varying redox conditions. Ecol Model 251:246-259

24. Lukkari K, Leivuori M, Vallius $H$, Kotilainen $A$ (2009) The chemical character and burial of phosphorus in shallow coastal sediments in the northeastern Baltic Sea. Biogeochemistry 94:141162

25. Luthy RG, Allen-King RM, Brown SL, Dzombak DA (2004) Bioavailability of contaminants in soils and sediments: Processes, tools, and applications. Soil Sediment Contam 13:155

26. Ma JJ, Wang PF, Ren LX, Wang X, Paerl HW (2019) Using alkaline phosphatase activity as a supplemental index to optimize predicting algal blooms in phosphorus-deficient lakes: A case study of Lake Taihu, China. Ecol Indic 103:198-712

27. Mort HP, Slomp CP, Gustafsson BG, Andersen TJ (2010) Phosphorus recycling and burial in baltic sea sediments with contrasting redox conditions. Geochim Cosmochim Ac 74:135-1362

28. Mozeto AA, Yamada TM, de Morais CR, do Nascimento MR, Fadini PS, Torres RJ, Sueitt APE, de Faria BM (2014) Assessment of organic and inorganic contaminants in sediments of an urban tropical eutrophic reservoir. Environ Monit Assess 186:815-834

29. Murphy J, Riley JP (1962) A modified single solution method for the determination of phosphate in natural waters. Anal Chim Acta 27:31-36

30. Paerl HW, Hall NS, Calandrino ES (2011) Controlling harmful cyanobacterial blooms in a world experiencing anthropogenic and climatic-induced change. Sci Total Environ 409:1739 
31. Paerl HW, Scott JT (2010) Throwing fuel on the fire: synergistic effects of excessive nitrogen inputs and global warming on harmful algal blooms. Environ Sci Technol 44:7756

32. Paerl HW, Scott JT, Mccarthy MJ, Newell SE, Gardner W, Havens KE, Hoffman DK, Wilhelm SW, Wurtsbaugh WA (2016) It takes two to tango: When and where dual nutrient (N \& P) reductions are needed to protect lakes and downstream ecosystems. Environ. Sci. Technol. 50

33. Paytan A, Roberts K, Watson SB, Peek S, Chuang PC, Defforey D, Kendall C (2017) Internal loading of phosphate in Lake Erie Central Basin. Sci Total Environ 579:1356-1365

34. Pearce AR, Rizzo DM, Watzin MC, Druschel GK (2013) Unraveling associations between cyanobacteria blooms and in-lake environmental conditions in Missisquoi Bay, Lake Champlain, USA, using a modified self-organizing map. Environ Sci Technol 47:14267-14274

35. Powell N, Shilton A, Chisti Y, Pratt S (2009) Towards a luxury uptake process via microalgae-defining the polyphosphate dynamics. Water Res 43:4207-4213

36. Powell N, Shilton AN, Pratt S, Chisti Y (2008) Factors influencing luxury uptake of phosphorus by microalgae in waste stabilization ponds. 42: 5958-5962

37. Puttonen I, Mattila J, Johanna P, Karlsson OM, Kohonen T, Kotilainen A, Lukkari K, Malmaeus JM, Rydin E (2014) Distribution and estimated release of sediment phosphorus in the northern Baltic Sea archipelagos. Estuarine Coastal Shelf Science 145:9-21

38. Qian J, Zheng SS, Wang PF, Wang C (2011) Experimental study on sediment resuspension in Taihu Lake under different hydrodynamic distrubances. J Hydrodyn 23:826-833

39. R. P, B., B, M., D, K., P, R., P, M., S (1988) Fractionation of phosphorus in suspended matter and sediment. Arch. Hydrobiol. Beih. 30: 98-109

40. Ren LX, Wang PF, Wang C, Chen J, Hou J, Qian J (2017) Algal growth and utilization of phosphorus studied by combined mono-culture and co-culture experiments. Environ Pollut 220:274-285

41. Ren LX, Wang PF, Wang C, Paerl HW, Wang HY (2020) Effects of phosphorus availability and the phosphorus utilization behavior by Microcystis aeruginosa on its adaptation capability to ultraviolet radiation. Environ Pollut 256:113441

42. Ren LX, Wang PF, Wang C, Peng ZC, Hu B, Wang RZ (2015) Contribution of alkaline phosphatase to phosphorus cycling in natural riparian zones in the Wangyu River running into Lake Taihu. Desalin. Water Treat.: 1-15

43. Reynolds CS (2006) Ecology of phytoplankton (Ecology, biodiversity and conservation): Cambridge University Press

44. Rigosi A, Carey CC, Ibelings BW, Brookes JD (2014) The interaction between climate warming and eutrophication to promote cyanobacteria is dependent on trophic state and varies among taxa. Limnol Oceanogr 59:99-114

45. Ruban V, López-Sánchez JF, Pardo P, Rauret G, Muntau H, Quevauviller P (2001) Harmonized protocol and certified reference material for the determination of extractable contents of phosphorus in freshwater sediments-a synthesis of recent works. 370: 224-228 
46. Ruttenberg KC, Dyhrman ST (2012) Dissolved organic phosphorus production during simulated phytoplankton blooms in a coastal upwelling system. Front Microbiol 3:274

47. Rydin E (2000) Potentially mobile phosphorus in Lake Erken sediment. 34: 2037-2042

48. Schindler DW (1977) Evolution of phosphorous limitation in lakes. Science 195:260-262

49. Sinkko H, Lukkari K, Sihvonen LM, Sivonen K, Leivuori M, Rantanen M, Paulin L, Lyra C (2013) Bacteria contribute to sediment nutrient release and reflect progressed eutrophication-driven hypoxia in an organic-rich continental sea. Plos One 8:e67061

50. Smith L, Watzin M, Druschel GK (2011) Relating sediment phosphorus mobility to seasonal and diel redox fluctuations at the sediment-water interface in a eutrophic freshwater lake. Limnol Oceanogr 56:2251-2264

51. Smith VH (2003) Eutrophication of freshwater and coastal marine ecosystems a global problem. Environ Sci Pollut Res Int 10:126-139

52. Smith VH, Tilman GD, Nekola JC (1999) Eutrophication: impacts of excess nutrient inputs on freshwater, marine, and terrestrial ecosystems. Environ Pollut 100:179-196

53. Tammeorg O, Horppila J, Laugaste R, Haldna M, Niemistö J (2015) Importance of diffusion and resuspension for phosphorus cycling during the growing season in large, shallow Lake Peipsi. Hydrobiologia 760:133-144

54. Wang JL, Fu ZS, Qiao HX, Liu FX (2019) Assessment of eutrophication and water quality in the estuarine area of Lake Wuli, Lake Taihu, China. Sci Total Environ 650(Pt 1):1392-1402

55. Wang PF, Ren LX, Wang C, Qian J, Hou J (2014) Presence and patterns of alkaline phosphatase activity and phosphorus cycling in natural riparian zones under changing nutrient conditions. $J$ Limnol 74:155-168

56. Whitton BA, Potts M (2002) The Ecology of Cyanobacteria: Springer Netherlands

57. Xie LQ, Xie P, Tang HJ (2003) Enhancement of dissolved phosphorus release from sediment to lake water by Microcystis blooms - an enclosure experiment in a hyper-eutrophic, subtropical Chinese lake. Environ Pollut 122:391-399

58. Xu H, Paerl HW, Qin BQ, Zhu GW, Gao G (2010) Nitrogen and phosphorus inputs control phytoplankton growth in eutrophic Lake Taihu, China. Limnol Oceanogr 55:420-432

59. Xu H, Yu G, Jiang H (2013) Investigation on extracellular polymeric substances from mucilaginous cyanobacterial blooms in eutrophic freshwater lakes. Chemosphere 93:75-81

60. Yao B, Xi BD, Hu CM, Huo SL, Su J, Liu HL (2011) A model and experimental study of phosphate uptake kinetics in algae: Considering surface adsorption and P-stress. J Environ Sci 23:189-198

61. Yao QZ, Du JT, Chen HT, Yu ZG (2016a) Particle-size distribution and phosphorus forms as a function of hydrological forcing in the Yellow River. Environ Sci Pollut Res 23:3385-3398

62. Yao Y, Wang PF, Wang C, Hou J, Miao LZ, Yuan Y, Wang T, Liu C (2016b) Assessment of mobilization of labile phosphorus and iron across sediment-water interface in a shallow lake (Hongze) based on in situ high-resolution measurement. Environ Pollut 219:873-882 
63. Zhang WZ, Gu P, Zhu WJ, Wang N, Zheng Z (2020) Phenotype changes of cyanobacterial and microbial distribution characteristics of surface sediments in different periods of cyanobacterial blooms in Taihu Lake. 54: 591-607

64. Zhang YL, Qin BQ, Zhu GW, Gao G, Luo LC, Chen WM (2006) Effect of sediment resuspension on underwater light field in shallow lakes in the middle and lower reaches of the Yangtze River: A case study in Longgan Lake and Taihu Lake. Science in China Series D 49:114-125

65. Zheng SS, Wang PF, Wang C, Hou J, Qian J (2013) Distribution of metals in water and suspended particulate matter during the resuspension processes in Taihu Lake sediment, China. Quatern Int 286:94-102

66. Zhou A, Tang H, Wang D (2005) Phosphorus adsorption on natural sediments: Modeling and effects of $\mathrm{pH}$ and sediment composition. Water Res 39:1245-1254

67. Zhou J, Qin BQ, Casenave C, Han XX, Yang GJ, Wu TF, Wu P, Ma JR (2015) Effects of wind wave turbulence on the phytoplankton community composition in large, shallow Lake Taihu. Environ Sci Pollut Res 22:12737-12746

68. Zhu MY, Zhu GW, Li W, Zhang YL, Zhao LL, Gu Z (2013) Estimation of the algal-available phosphorus pool in sediments of a large, shallow eutrophic lake (Taihu, China) using profiled SMT fractional analysis. Environ Pollut 173:216-223

\section{Figures}



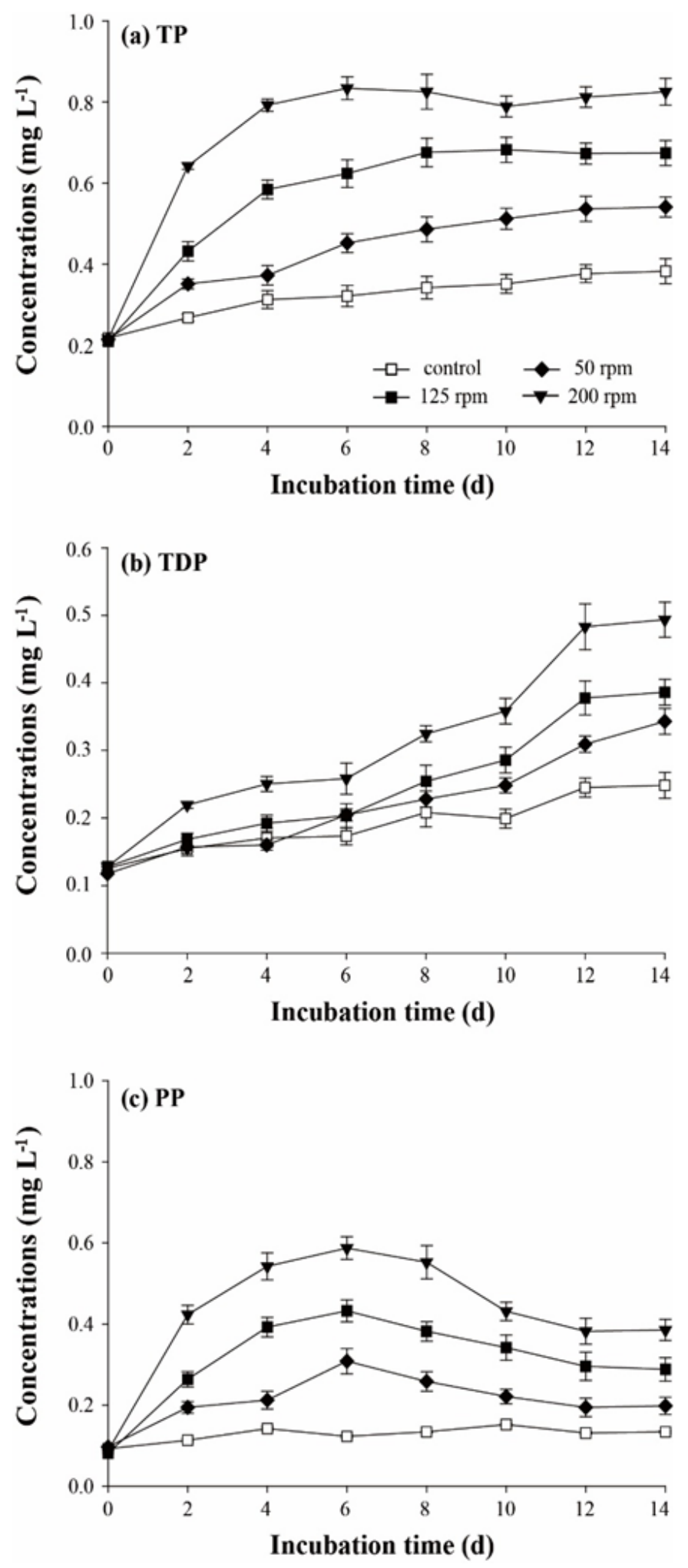

Figure 1

(a) TP, (b) TDP and (c) PP concentrations in the overlying water in SW system. 
Concentration $\left(\mathrm{mg} \mathrm{L}^{-1}\right)$
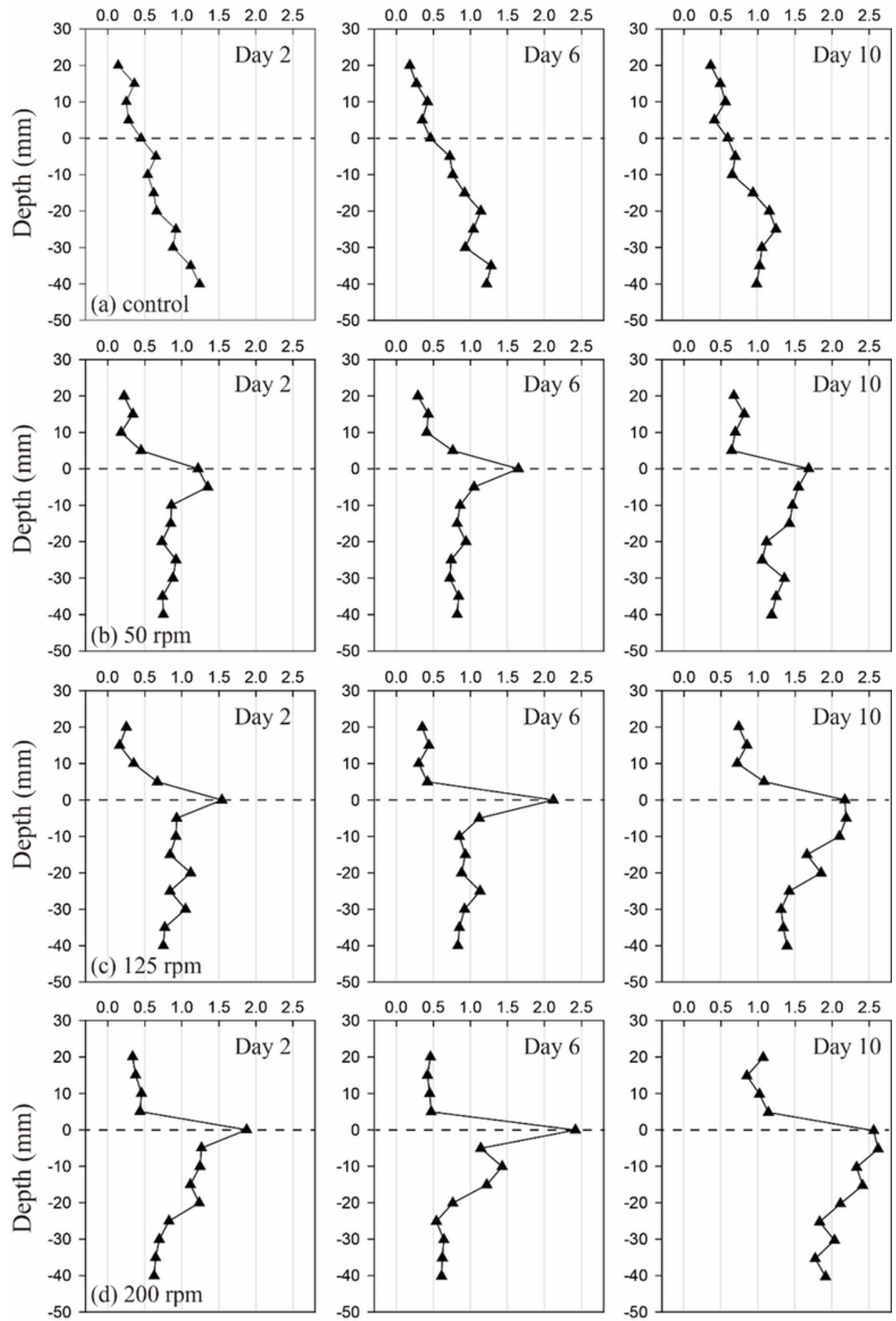

Figure 2

TDP concentration in the water near SWI in SW system. 

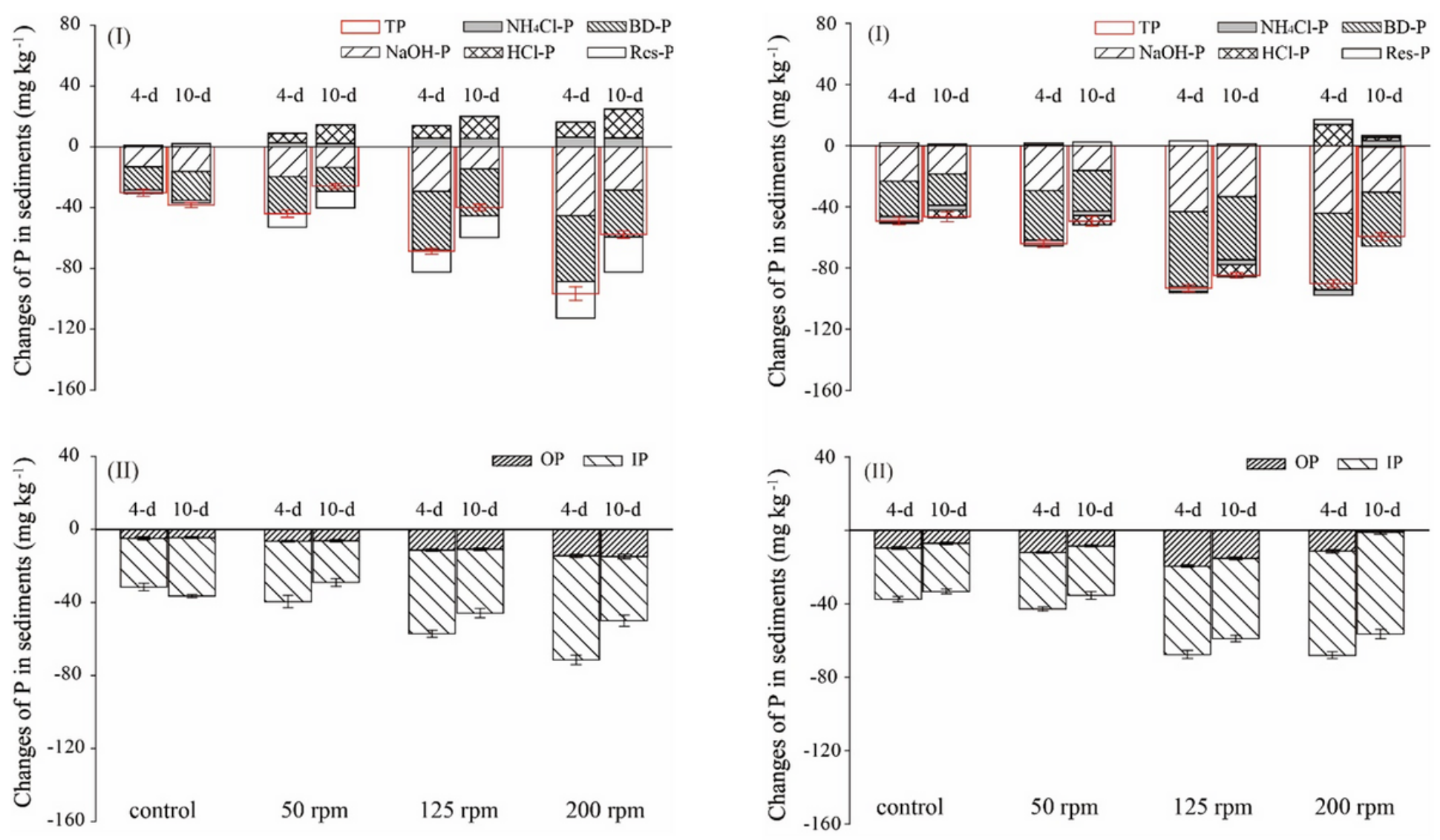

a

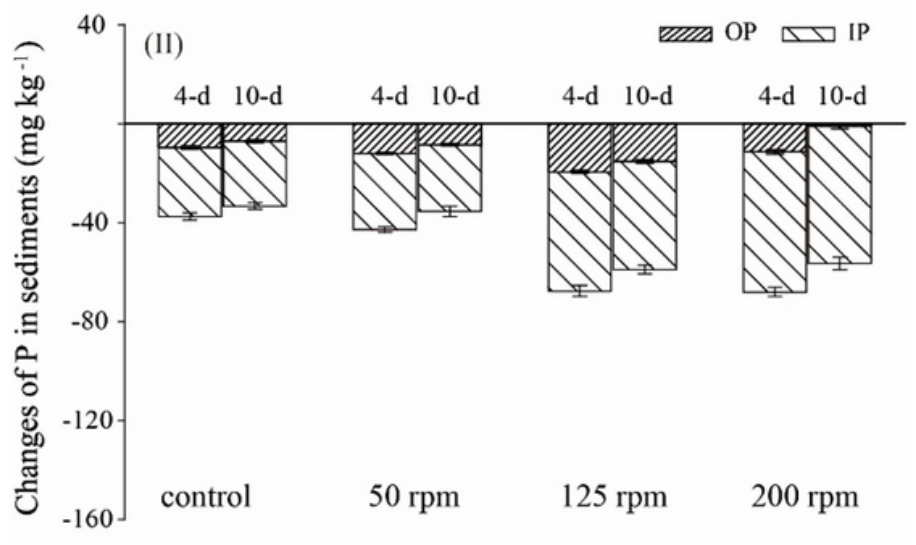

$\mathrm{b}$

Figure 3

Changes of P fractions in the sediment on Day 4 and Day 10 in (a) SW system, and (b) SAW system. 
(a) DO content $\left(\mathrm{mg} \mathrm{L}^{-1}\right)$
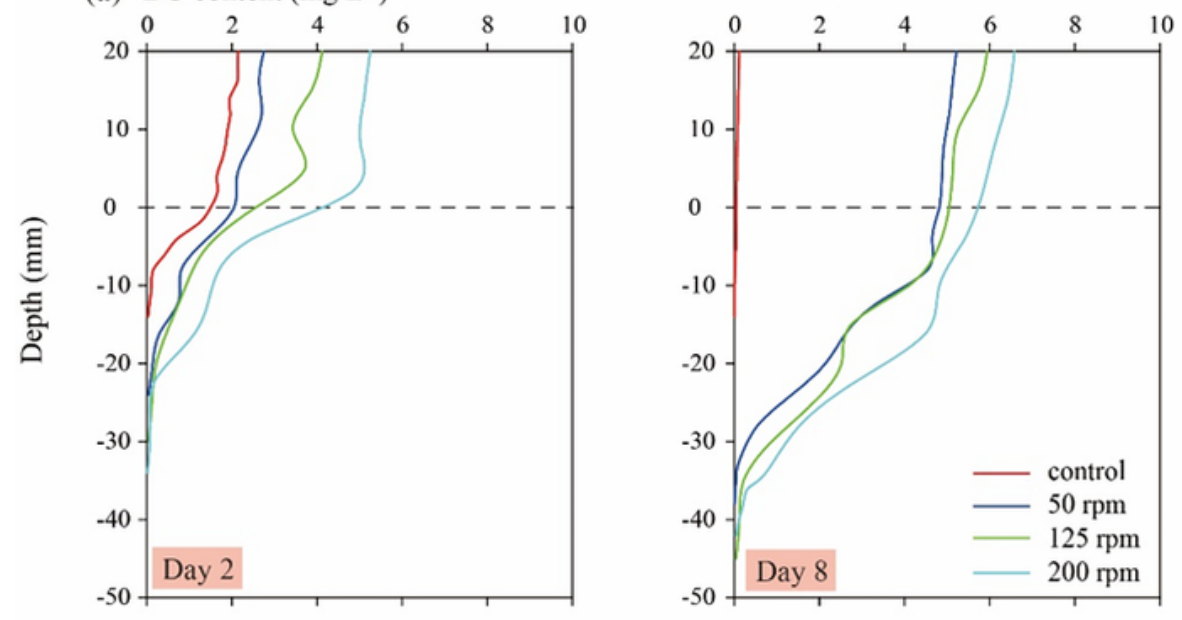

(b) Redox potential $(\mathrm{mV})$
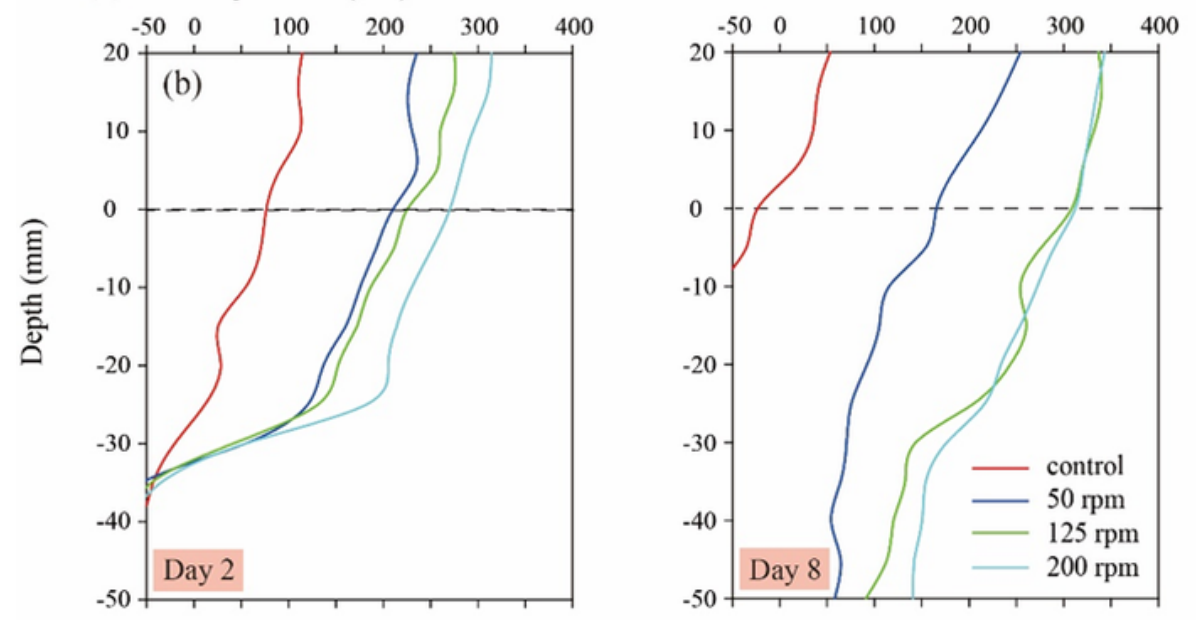

(c) Size of suspended particles
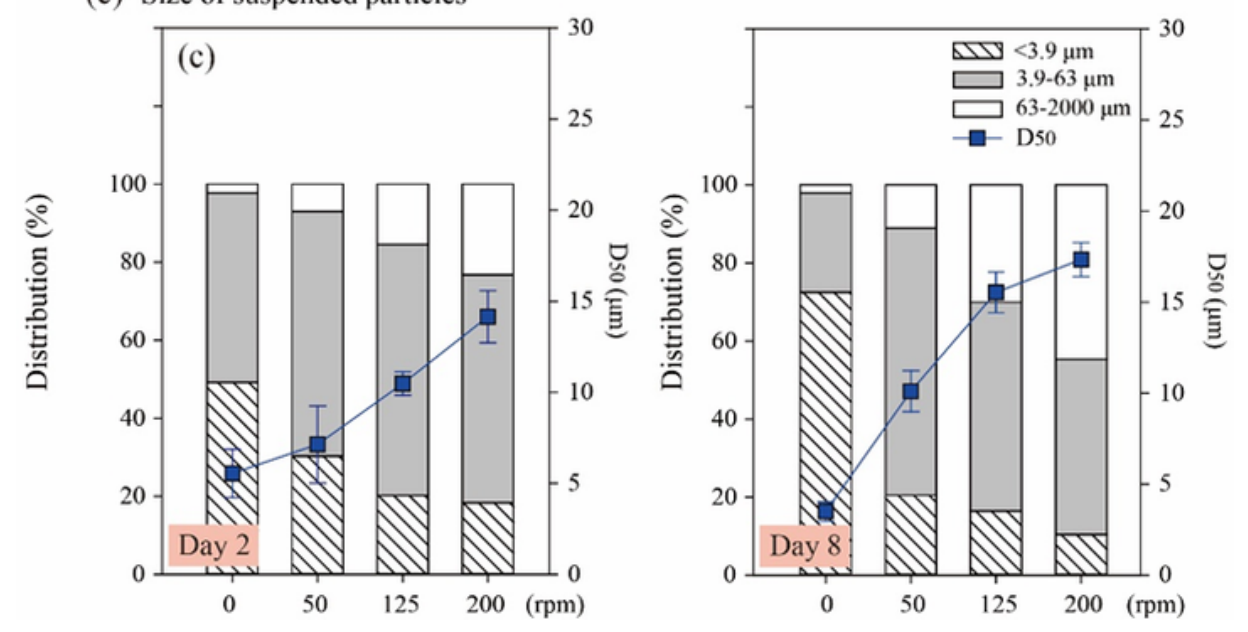

\section{Figure 4}

(a) DO content, (b) redox potential near SWI, (c) size of suspended particles (size composition and the average median particle size) in SW system. 


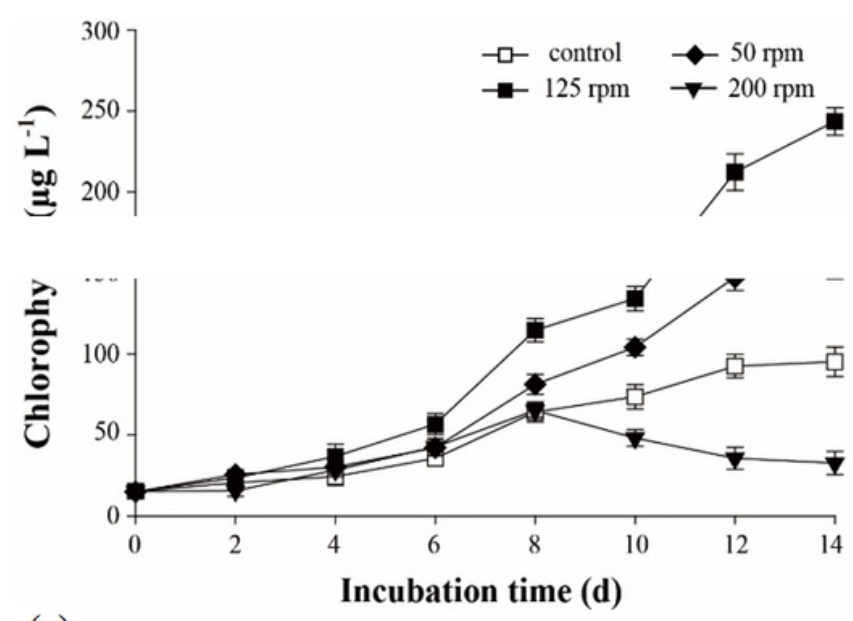

(a)

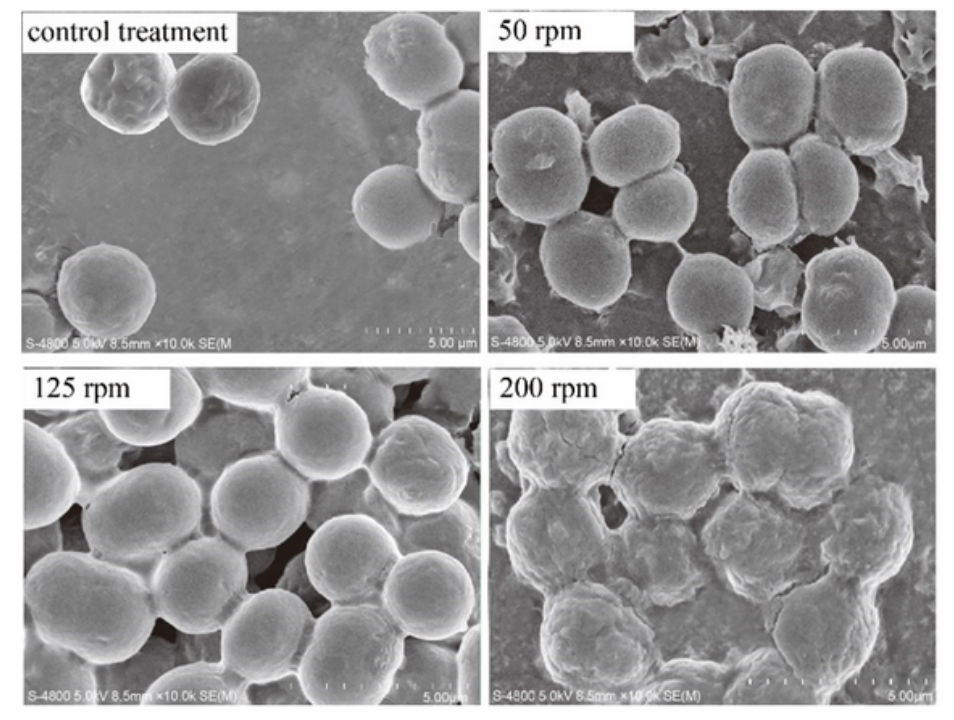

(b)

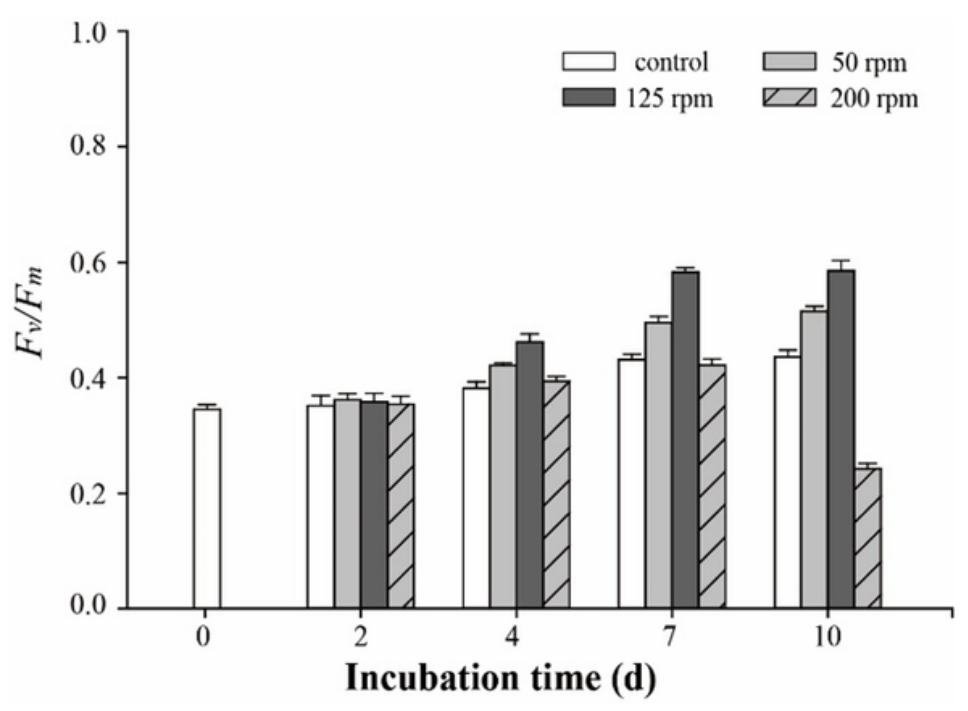

(c)

\section{Figure 5}

Growth of M. aeruginosa in SAW system determined by (a) chl-a content, (b) SEM images on Day 8 and (c) Fv/Fm. 


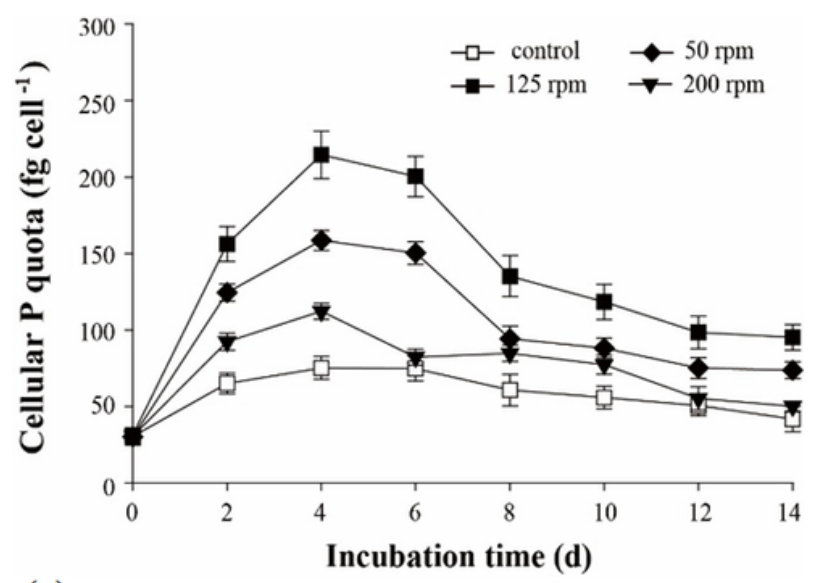

(a)

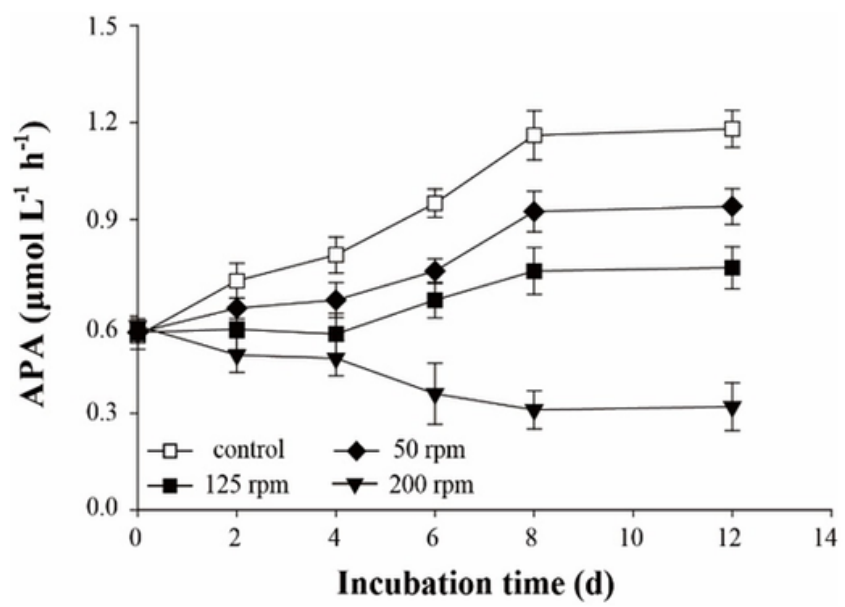

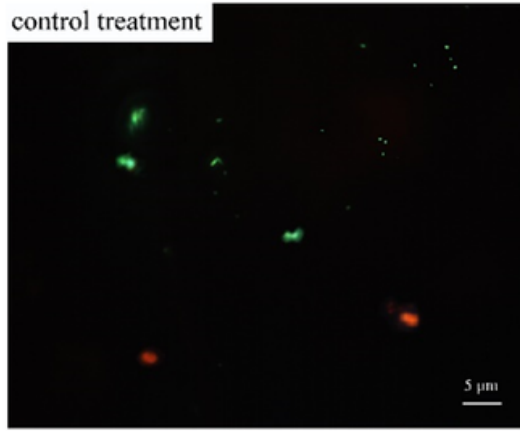

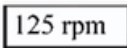 \\ $125 \mathrm{rpm}$}

*
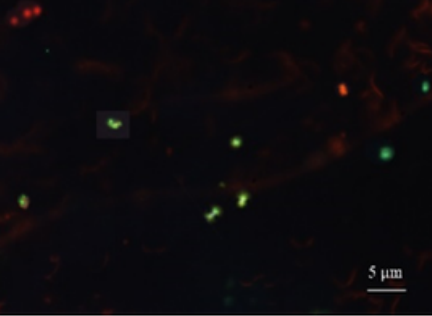

(c)

(b)

Figure 6

(a) Cellular P quota, (b) APA of M. aeruginosa, and (c) FLEA images on Day 8 in SAW system (Green and red colors indicate fluorescence on the sites producing APA and chlorophyll a auto-fluorescence, respectively). 

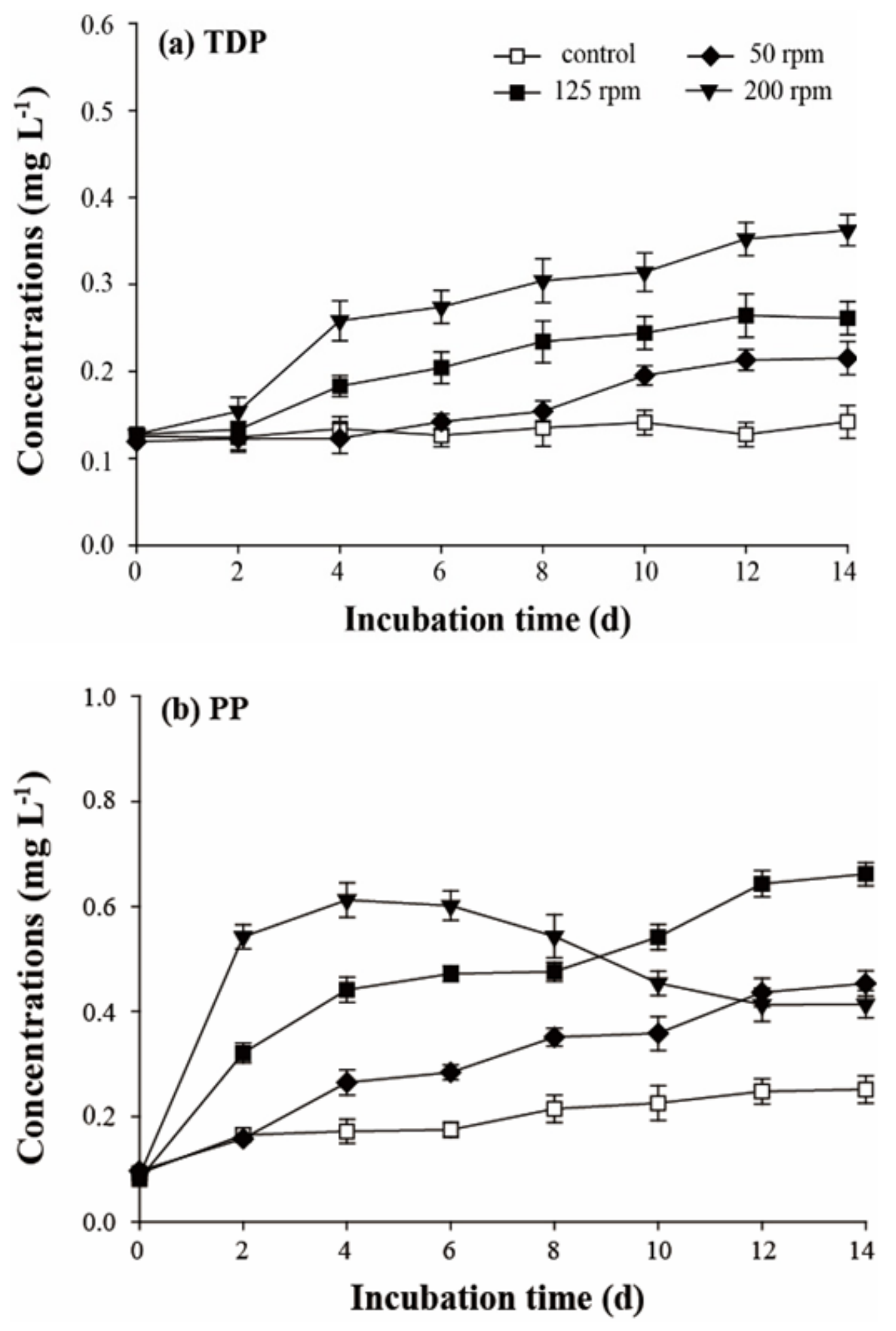

Figure 7

(a) TDP and (b) PP concentrations in the overlying water in SAW system.

\section{Supplementary Files}

This is a list of supplementary files associated with this preprint. Click to download. 
- SupplementaryInformation.docx

Page 25/25 